\title{
1 Mapping the Chinese Heritage Regime
}

\author{
Ruptures, Governmentality, and Agency \\ Marina Svensson and Christina Maags
}

Maags, Christina \& Marina Svensson(eds), Chinese Heritage in the Making: Experiences, Negotiations and Contestations. Amsterdam: Amsterdam University Press, 2018

DOI 10.5117/9789462983694/CHO1

\begin{abstract}
The chapter introduces the reader to the edited volume. It explores cultural heritage policy and practice in China by making use of concepts and theories from both heritage studies and China studies. Reviewing the state of the art, there is a need to examine the development of the Chinese authorized heritage discourse as a tool of governmentality against the backdrop of local contestations, negotiations and appropriation. The chapter familiarizes the reader with the various sections of the book which draw attention to the plurality of local forms of contestations unfolding in a bottom-up manner.
\end{abstract}

Keywords: cultural heritage, China, authorized heritage discourse, governmentality, contestation

\section{Critical heritage studies and China}

This edited volume takes as its starting point the critical approach to heritage studies promoted by the Association of Critical Heritage Studies. Initiated in 2010, the association held its first conference at the University of Gothenburg in 2012. In its manifesto, the association makes an appeal to 'question the received wisdom of what heritage is, energize heritage studies by drawing on wider intellectual sources, vigorously question the conservative cultural and economic power relations that outdated understandings of heritage seem to underpin and invite the active participation of people and communities who to date have been marginalized in the creation and management of "heritage"' (ACHS 2012). To achieve this aim, the association argues that 'truly critical heritage studies will ask many uncomfortable 
questions of traditional ways of thinking about and doing heritage, and that the interests of the marginalized and excluded will be brought to the forefront when posing these questions' (ACHS 2012). Without claiming that previous work in heritage studies has not been critical, we agree with Winter (2013) and others in arguing that critical heritage studies should go beyond criticizing heritage policy or practice and focus more on critical issues of the time. By this we mean 'critical issues which face the world today, the larger issues that bear upon and extend outward from heritage [...] such as cultural and environmental sustainability, economic inequalities, conflict resolution, social cohesion and the future of cities' (Winter 2013: 533, emphasis in the original).

Since the association's manifesto, scholars have continued to elaborate on what critical heritage studies actually means. Winter $(2013,2014)$ has, for example, also criticized the Eurocentric bias in heritage studies and argued that we need to be open to different understandings from other societies, and that this should influence how we theorize cultural heritage. One needs to understand how heritage production is shaped by particular political and socio-cultural contexts and address the major global social and cultural shifts. Winter thus makes a call to 'provincialize', or we could say 'de-Westernize', heritage studies. Other scholars, such as Waterton and Watson (2013) in their discussions on a 'critical imagination' in heritage studies, have differentiated between theories in, of, and for heritage. While theories in heritage focus more on the objects of heritage and matters of authenticity, conservation, interpretation, and visitors to heritage sites, theories of heritage study heritage as a system of production and combine representational theory with discursive analysis in order to understand the political nexus of heritage. Theories for heritage focus on 'the role played by the personal, the ordinary and the everyday, within spaces of heritage, whether they are physical, discursive or affective' (Waterton and Watson 2013: 551). A critical approach to heritage studies thus asks us to go beyond disciplinary boundaries and understandings of heritage and take a broader, non-Western, interdisciplinary, and context-based perspective to heritage that pays particular attention to power relations and marginalized voices in different societies.

We hope that this volume can contribute to the growing field of critical heritage studies and address the calls to develop stronger theoretical frameworks and perspectives that build on a deep engagement with non-Western societies. We therefore set out to explore cultural heritage policy and practice in China, making use of concepts and theories from both heritage studies and China studies. In the following we will further 
analyse our use of some central concepts such as the Authorized Heritage Discourse (AHD), while paying close attention to its configuration in the Chinese case and ruptures over time. We share the view that heritage is always in the process of 'making', and thus should be understood as a 'verb' rather than as a 'noun' (Harvey 2001), and therefore aim to scrutinize the heritagization process and what heritage discursively and materially does to objects, places, and people. This also requires that we focus on the social and political construction of heritage for contemporary needs, heritage as a site of negotiations and contestations over identities, memories, and place-makings among different actors and stakeholders with different social and cultural capital and agency, leading us to also analyse heritage as a tool of governance and address the concept of governmentality. In line with recent works within heritage studies, we pay attention to performativity, emotions, sentiments, and people's affective engagement with heritage, and engage in more bottom-up analyses of how people appropriate, negotiate with, and challenge the AHD. Furthermore, we explore whether and how the Internet and social media today provide space for multiple and more diverse voices and heritage from below.

The People's Republic of China (PRC) is a highly relevant case for a critical heritage studies approach due to its recent and dramatic 'heritage boom' and rapid socio-economic changes that give rise to new challenges and contradictions. The explicit political use of heritage makes it compelling to analyse power relations, governmentality, and issues of negotiations and resistance. The Chinese case, however, also alerts us to the complexity of any attempts to 'de-Westernize' heritage studies as it illustrates both the universal pull of the language of heritage and thus the globalizing forces inherent in heritagization processes, while also reminding us of the fact that countries such as China are increasingly leaving their mark on the global heritage regime through an active involvement in the United Nations Educational, Scientific and Cultural Organization (UNESCO). Whilst it might be tempting to talk about heritage with 'Chinese characteristics', one needs to remember that global and local forces interact and may be difficult to disentangle (Harrell 2013: 287). Furthermore, ruptures in the Chinese AHD have occurred due to ideological shifts and socio-economic developments. Heritage production in China is shaped by its communist political system as much as by its pre-communist past. 'China' itself also needs to be scrutinized as there are many different views on heritage within the country that illustrate regional, cultural, and ethnic differences as well as gaps between 'heritage professionals' and the general public. Heated debates and contestations today take place in Chinese society but attempts 
to base views on heritage in the Chinese tradition and history do not necessarily sit well with a Chinese state that still, at least on a rhetorical level, calls itself Marxist.

The Chinese state, albeit still ruled by the Chinese Communist Party (CCP), is characterized by increasing political, institutional, and societal fragmentation. The impact of the market economy and globalization has made the country depart radically from the old-style type of communist system of the Mao Zedong era. The starting point for the 'heritage turn' in the 1990 s is to be found in ideological shifts and the CCP's search for a new form of legitimacy beyond communism (Denton 2005; Long 2012; Madsen 2014). There is a growing pride in the country's long history and rich traditions, affirmation of erstwhile condemned cultural values, huge investment in heritage protection, and promotion of a culturally based nationalistic discourse. The new vocabulary and ways to conceptualize the past in terms of cultural heritage (wenhua yichan) has changed how historical sites and cultural traditions are imagined, valued, and interpreted. But this does not mean that all aspects of the country's past and its traditions are now embraced. There is selectivity in the choice of sites and practices elevated to heritage status, attempts to govern and control cultural and religious practices through the heritage discourse, and continuing tensions between a state-led national discourse and bottom-up celebrations of local cultures and identities.

The nationalistic rhetoric and rediscovery of heritage sites and practices, however, finds a deep resonance among large groups of people. The ideological vacuum and sense of a lack of values in society, coupled with large-scale displacements due to migration and urbanization, growing inequalities in the wake of the economic reforms, and the influx of Western popular culture, have led to a growing sense of uncertainty that has stimulated individuals' search for their roots, nostalgia for the past, and interest in local history and traditional culture. Many Chinese citizens are deeply concerned about perceived threats to Chinese culture and the destruction of the rural and urban historic built environment. This concern and interest in some ways mirrors heritage movements elsewhere in the world that also have been spurred by rapid socio-economic changes and anxieties in the face of modernization and globalization (Dicks 2003; Germundsson 2005).

The critical heritage studies approach is well suited and attuned to China studies since scholars have long engaged in critical studies of CCP ideology, cultural policies, and the fragmented nature of the Chinese political system - issues that are of relevance in order to understand cultural heritage policy and management. Many scholars have drawn attention to the importance of 
CCP ideology and ideological shifts for understanding heritage polices (see e.g. Denton 2014; Oakes 2013; Madsen 2014; Silverman and Blumenfield 2013). Several authors in this volume, including, for example, Cooke and Zhang, also address ideological shifts and their impact on the evaluations, interpretations, and management of historic sites. In addition, the fragmented authoritarian system alerts us to variations and discrepancy between national and local policies and between different institutions (Lieberthal and Oksenberg 1988). The chapters by Graezer Bideau and Yan, as well as by Maags, address how hierarchies and fragmented power structures shape heritage policies; whereas Cui's chapter is a particularly striking example of how individual political leaders and a strong tradition of 'rule by men' shape the heritage landscape. However, it is important not to privilege a state-centred approach since nowadays there is more scope for civil society and individual citizens to explore and celebrate local traditions and history. Heritage-making processes, however, often privilege elites and the middle class in their cultural and leisure activities (Light et al. 1994), a section of the populace which has grown significantly in China over the last decade (Li 2011). Yet, although the state and elites have a privileged access to and voice in heritagization processes, ordinary citizens, local communities, and marginalized groups have more abilities to express their views, negotiate, appropriate, and resist the AHD or its implementation, as discussed in Blumenfield, Chan, Cui, Graezer Bideau and Yan, Maags, Svensson, and Tam.

\section{The authorized heritage discourse: Western roots and new actors}

Smith (2006) is credited for having developed one of the most prominent concepts to emerge in the field of heritage studies in recent years. She argues that the international heritage regime, embodied in universal conventions, policies, and laws, produces an AHD which 'establishes and sanctions a top-down relationship between expert, heritage site and "visitor", in which the expert "translates"' this discourse into national policies and laws (Smith 2006: 34). Since the AHD is based on a Western material understanding of heritage, international experts have obtained the right to determine what qualifies as heritage and how it should be protected, thereby marginalizing vernacular understandings of heritage (Smith 2006: 34-35). Henceforth, scholars have talked about a 'discursive turn' in heritage studies (Harrison 2013). Whereas others such as Hafstein (2012) argue that 'cultural heritage creates a discursive space in which social changes may be discussed and it provides a particular language for discussing them [...] at the same time, 
the terminology of heritage is a mechanism of power: it curtails expression by defining the sort of things that it makes sense to say' (Hafstein 2012: 507). To date, a number of works have incorporated the concept of AHD into their analysis in order to criticize and contest the dominance of Eurocentric notions of heritage in the international realm $\mathrm{Wu}$ and Hou 2015) and demonstrate how actors counter this dominance by developing alternative discourses or heritage from below (Haldrup and Bærenholdt 2015; Robertson 2012).

Some scholars have however criticized the concept of AHD for deemphasizing the role of the nation state and the influence of local power structures. Askew (2010), for instance, has noted that the claim that 'the so-called 'Authorized Heritage Discourse' (for which UNESCO is the principle global-level purveyor) is Eurocentric and crypto-imperialist is both redundant and a conceptual red herring: it misrecognizes the real locus of power and exploitation in the global heritage game which is the nationstate and not any dominant global institutional structure or discourse of heritage classification' (Askew 2010: 21-22). In a similar vein, scholars have pointed out the existence of different national authorized heritage discourses and, for example, how the official Chinese AHD comprises a mixture of the international AHD and Chinese indigenous concepts and discourses (see Nitzky 2012a; Wu 2012b; Yu 2015; Zhu 2015). Although the AHD is a useful tool to understand how global heritage values have developed and shaped policies, laws, and practices, it tends to ignore how countries develop their own specific versions of AHD and the mixture of local and global values, or why and how different countries embrace the UNESCO discourse.

While Smith criticized the strong focus on tangibility in the Westerndominated AHD, it appears that a new AHD focusing on the intangible cultural heritage (ICH) has emerged and shaped heritage policies since 2003, yet exhibits many of the same problems as well as creating new ones. Smith (2015), for instance, notes that 'Rather than opening Pandora's Box, the development of the ICHC has tended to add yet another category to established international understandings of heritage (natural and cultural), and has yet to fundamentally redefine the conceptual frameworks within which heritage is understood' (Smith 2015: 133-134). In this context, it also needs to be acknowledged that non-Western countries such as Japan, South Korea, and China have been heavily involved in this shift and are co-producers of the new emerging AHD (Hafstein 2009: 96-99). Since ratifying the UNESCO Convention for the Safeguarding of Intangible Cultural Heritage (ICHC) in 2004, as the sixth country worldwide, China has had a 
dominant position within the UNESCO World Heritage Committee, handing in the most nominations over the years, sending the largest delegations to the UNESCO meetings, and in general enlarging its influence within the Committee by collaborating with other BRICS countries (Meskell et al. 2015: 9-10). China today has the second largest amount of world heritage sites (48) and the largest amount of ICH practices (38) listed worldwide (UNESCO 2016a; UNESCO 2016b). China is also stepping up its heritage diplomacy efforts by organizing ICH festivals (UNESCO 2015) and taking the lead in inscribing the Silk Road on the list of World Heritage Sites, together with Kyrgyzstan and Kazakhstan (UNESCO 2014).

\section{The development of a Chinese authorized heritage discourse: Ideological ruptures and new global aspirations}

More attention needs to be devoted to how individual countries develop their own AHD, and how they reflect local conditions, ideologies, and aspirations. China has developed a unique AHD that has undergone many ruptures, shifts, and striking changes since 1949. While many of them reflect domestic concerns, China's global aspirations and increasing involvement in UNESCO have had a deep impact since the 1980s. Cultural heritage fulfils many functions. It is linked to political goals and serves as a resource for political legitimacy and soft power, but it is also regarded as an economic asset and used to boost local economic development.

When the CCP obtained political power in 1949, it challenged and refuted the historiography, cultural manifestations, and heritage policies of the old political and economic elites. The heritage of those that the CCP identified as 'class enemies', such as capitalists, landlords, lineages, and different religious groups, was destroyed, desecrated, and condemned. The remaining historic sites and cultural artefacts were then reinterpreted and rewritten through an ideological and political lens that defined them as feudal, backward, and superstitious. They were sometimes only preserved because they could serve as monuments of the 'bad' old days of feudalism, colonialism, and capitalism. During the Mao Zedong era, sites associated with revolutionary events and figures and collections of revolutionary objects were privileged. The attacks and destruction of old cultural artefacts and sites reached a feverish height during the Cultural Revolution, although sites and collections considered of national importance, including the Forbidden Palace, were spared on orders from the highest leadership. The new economic policy implemented in the 1980 os made the CCP turn 
away from the class struggle and revolutionary rhetoric of the past. This ideological shift entailed more tolerance of religious beliefs and traditional cultural practices, as well as a re-evaluation of China's past. The country's rich cultural heritage now became a source of national pride and much work was put into listing, protecting, and restoring hitherto neglected sites and buildings (Gao 2008: 20-36). When we look at lists of heritage sites from the late 1980 on onwards, we see how the proportion of revolutionary sites has diminished, giving way to imperial sites, and how the concept of heritage has also expanded to include vernacular buildings in the countryside, for example, ancestral halls and whole villages, as well as industrial sites and more recent buildings.

Generally speaking, we can detect a development over time within the official cultural heritage discourse, from an almost exclusive focus on the revolutionary heritage in the Mao Zedong period, to a focus on China's imperial past and a more culturally based patriotic heritage narrative in the 1980 s, to a discovery and celebration of more diverse heritage in the 1990s that also includes vernacular and industrial heritage; and finally to the adoption of the concept of intangible cultural heritage since 2003. This development can be traced through studying shifts in ideology and cultural policy that manifest themselves in different heritage and museum policies, sets of heritage listings at the national and local level, and in institutional and legislative changes (Denton 2005; Silverman and Blumenfield 2013; Svensson 2011). However, the CCP's revolutionary heritage remains important for ideological reasons and shapes narratives of patriotic education in museums and different sites (Denton 2014; Long 2012; Wang 2012).

One of the most dramatic shifts has occurred with China's signing of the UNESCO Intangible Cultural Heritage Convention in 2003. China has become an enthusiastic champion of intangible cultural heritage with 38 practices on the UNESCO list, including seven on the list of threatened practices (UNESCO 2016b), 1372 items on the national list, and 1986 national-level transmitters (for a discussion on ICH and transmitters, see Blumenfield, Maags, and Svensson). China had undertaken an extensive and impressive documentation of cultural practices, established new institutions in charge of nominating and supervising these practices, and also adopted several policies and a new law in order to better manage intangible heritage at different levels of the administrative system (on China's intangible heritage system and specific items, see Bodolec 2012; Maags and Holbig 2016; Obringer 2011; Kuah and Liu 2017). There is certainly a bias in the selection and nomination process at different levels and much competition between different regions. As several authors 
have pointed out, the adoption of the intangible heritage discourse means that many cultural practices, including religious rituals that were seen as 'superstitious' practices in the past, are now celebrated as heritage (Gao 2014; Liang 2013). In this heritagization process many of them have been reconstructed and reinterpreted, and some have had their religious aspects downplayed or ignored. Showing the political uses of heritage, the ICH law of 2011 states in Article 4 that: ' $[\mathrm{t}$ ] he protection of ICH [...] is conductive to enhancing the Chinese national cultural identity, to safeguard national identity and national unity and to protect social harmony and sustainable development'. Heritage protection is thus part of an attempt at national revival, most recently formulated as the China Dream under Xi Jinping, and the construction of a 'spiritual home' (jingshen jiayuan) of the Chinese nation where a pre-Communist past, somewhat ironically, is increasingly important for the CCP's legitimacy.

The dramatic shifts and ruptures in how heritage has been understood, valued, and interpreted are tellingly illustrated in Cooke's chapter on the Nationalist Party (Guomindang) legacy and ethnic warlords, as well as in Zhang's chapter on colonial heritage. How the Chinese AHD is produced, circulated, and implemented at different levels, and how it is appropriated, negotiated, and resisted by individuals and communities, is addressed in the chapters by Blumenfield, Chan, Cui, Maags, and Svensson. The attraction of UNESCO listing for the central government and local governments reflects both ideological, i.e. soft power, and economic interests. Local governments' attempts to gain international recognition, complex bidding processes, and diverse outcomes for local communities and individuals are discussed in the chapters by Blumenfield, Laukkanen, and Svensson (for other discussions on World Heritage Sites and ICH in China, see Hevia 2001; Liang 2013; Obringer 2011; Wang 2010; Zhu and Li 2013).

\section{Heritage and governmentality}

China has established an extensive heritage management system with national and regional inventories of heritage sites and cultural practices. The State Administration of Cultural Heritage (SACH) administers China's large amount of cultural relics and tangible cultural heritage, whereas the Ministry of Culture has established an Intangible Cultural Heritage Department to safeguard the intangible cultural heritage. Their work is supported and regulated by different laws, regulations, and policies. Whereas experts and intellectuals are involved in surveys on local heritage and also advise 
on policy formulation and management, local communities and cultural practitioners are largely excluded from the heritage-making process (Maags and Holbig 2016) as discussed, for example, in the case of Beijing in Graezer Bideau and Yan and Yunnan in Laukkanen.

Heritage listings and management is not an innocent and non-political celebration of heritage and culture, but a selective process that leads to hierarchies and exclusion. It can furthermore be used as a tool of governance to control and manage tradition, cultural practices, and religion, and to steer people's memories, sense of place, and identities in certain ways. Several scholars (Hafstein 2014; Beardslee 2015; Combe 2015) have pointed out that the use of culture and intangible cultural heritage can be a softer and less visible way of 'rendering individuals governable'. The listing, reification, and celebration of certain cultural practices can thus be a tool of governance, especially when individuals and communities are excluded from decisionmaking but still come to internalize the validation of the selected practices and behaviours. In the context of China, ICH could be seen as a new form of governance and a way to control religious and ethnic communities in particular (Kang 2009; Liang 2013; Oakes 2013; Silverman and Blumenfield 2013). The ambivalent official attitude to religion and ethnic cultures are well illustrated in the chapters by Laukkanen on Tibetans in Yunnan and Cooke on minorities in Qinghai.

In order to understand negotiations between various state and non-state actors on different scales or levels, Bendix et al. use the concept 'heritage regimes', defined as 'a set of rules and norms regulating the relations between a state-government and society' (2012:12). The term 'regime' draws our attention to the interplay between the international heritage regime, manifested in international conventions and policies, and the national governance structures responsible for implementing international conventions according to domestic procedures (Bendix et al. 2012: 12-13). In the context of China, Oakes (2013) has pointed out that local governments frequently appropriate heritage as a tool of governance to enhance social cohesion and promote modernization and development. Harrell (2013) also sees heritage policy as 'part of the modernizing effort, which in turn is part of China's continuing process of nation-building' (2013: 287). Yet, as 'heritage preservation emerges amid a complex and often contradictory mixture of global perspectives on heritage preservation, state traditions of cultural regulation, and local yearnings for modernity and improved standards of living' (Oakes 2013: 380), it simultaneously creates many instances of contestation, negotiation, and conflict among the different stakeholders involved. 


\section{Contestations, negotiations, and appropriation: Plural voices and diverse interests}

It is widely recognized that heritage is a social construction and a site of contestations due to the multiple forms, meanings, values, and emotions associated with heritage sites and practices. Tunbridge and Ashworth (1996) argue that heritage-making processes are always contested by different stakeholders and therefore 'dissonant' in nature. With the notion of dissonance they draw our attention to the fact that 'heritage creation is controversial in a number of respects [...] [as it] involves a discordance or lack of agreement and consistency [...] [and] a state of psychic tension caused by simultaneous holding of mutually inconsistent attitudes or the existence of a lack of consonance between attitudes and behavior. [...] At its simplest, all heritage is someone's heritage and therefore not someone else's' (1996: 20-21). Silverman (2011) argues that a paradigm shift has occurred since the heritage literature now 'regards heritage as contested, recognizes the role of power in the construction of history, focuses on the production of identity, emphasizes representation and performance, and preferentially analyzes formerly colonial states and societies and their subaltern populations' (2011: 5). Heritage contestations are not only cultural or political in character but also occur over economic benefits since heritage today is an important economic asset for both governments and individuals (Ashworth 2014). Several authors in this volume, for example, Blumenfield, Laukkanen, and Maags, discuss whether and how individuals and local communities benefit economically from heritage status and the contestations that inevitably also occur.

Heritage is, however, also a discourse that can be used as a resource for identity politics, social mobilization, and resistance. The heritage turn in China has created the scope for more bottom-up debates on national and local history and traditions, and also encouraged new actors to become involved. As a plurality of stakeholders seeks to gain a say in what historical remains become heritage and how they are used, windows of opportunity may open up spaces for 'heritage from below' (Robertson 2012) that contest official sanctioned discourses and practices. Here it is imperative to ask which actors are involved, and whether we see new interpretations and forms of engagements, or whether and how different actors are co-opted within or appropriate the official heritage discourse.

The growing importance of heritage in Chinese cultural, political, and economic life has given rise to a range of actors and stakeholders involved in heritage-making and negotiating the AHD. They include experts and 
scholars, often working in close cooperation with government bodies, civil society organizations, informal networks of enthusiasts, transmitters, who as a new group personify and embody ICH, and local communities. These groups and roles cannot always be neatly separated but are in reality often blurred and converge as individuals take on multiple roles or move between different positions. These individuals and groups are today debating, performing, and consuming a diverse cultural heritage. Individual citizens and local communities are, for example, embracing the heritage discourse when celebrating their own histories, identities, and traditions, or when seeking legitimacy for their cultural practices, as discussed by Chan in the case of the Hungry Ghosts Festival in Hong Kong. Experts who work within, or at times for heritage bodies, as well as scholars, authors, artists, journalists, and other vocal individuals with a strong social and cultural capital, often speak out on behalf of heritage preservation and could be described as heritage 'middle-men' (Beardslee 2015). Several scholars have drawn attention to the role of intellectuals and journalists in heritage preservation debates in China (Nitzky 2013; Svensson 2012a), as also discussed in the cases of Beijing (Graezer Bideau and Yan), Datong (Cui), Yunnan (Blumenfield), and Taishun (Svensson) in this volume. In some cases, citizens are resisting the AHD or maintaining vernacular heritage narratives and practices outside of the official discourse (Yu 2015; Zhang and $\mathrm{Wu}$ 2015). However, the difficulties for local communities to maintain their own understanding and control of local heritage in the face of powerful new stakeholders are illustrated in Laukkanen's chapter on Yunnan and Cooke's chapter on Qinghai.

\section{Performativity, emotions, and affect: Beyond representational understandings of heritage}

Smith (2006) argues that heritage is essentially a performance of reminiscences that are filled with personal emotions and memories (2006: 66-67). Harrison also reminds us that it is 'important to bring the affective qualities of heritage "things" more squarely back into the critical heritage studies arena [...] [and to explore] its corporeal influences on the bodies of human and non-human actors, and the ways in which heritage is caught up in the quotidian bodily practices of dwelling, travelling, working and "being" in the world' (2013: 112-113). There is also a growing focus on emotions and affect within heritage studies (Waterton and Watson 2013; Waterton 2014; Crouch 2015). These works alert us to the centrality of feelings, emotions, 
and affect in people's engagement with heritage, and how heritage is evoked, felt, and experienced. The emotional, embodied, and affective engagement with heritage is obvious in many of the chapters in this book. The strong emotional sentiments and responses to heritage are evident in the heated debates on urban developments that took place in Datong (Cui) and Beijing (Graezer Bideau and Yan; Tam). The affective and embodied responses to heritage are also evident in the way people from Taishun relate to their heritage (Svensson), and how Tibetans in Yunnan experience their heritage (Laukkanen).

\section{Tangible and intangible heritage: Problematic dichotomies and contested issues}

The international heritage regime for a long time emphasized tangible cultural heritage and has only recently included the concept of intangible cultural heritage as a special category. The resulting dichotomy, however, creates many problems, since, as several scholars have pointed out, 'all heritage is intangible' (Smith 2006:3) and material objects first need to be endowed with values in order for them to become heritage (Kuutma 2009: 7). Bortolotto (2007) nevertheless reminds us that the conceptualization of heritage is deeply embedded in historical processes. She argues that " $\mathrm{r}]$ ather than considering the two categories of "tangible" and "intangible" as opposed, it seems in fact more appropriate to consider them within the framework of a constructivist approach as the answer to particular historical situations and needs' (Bortolotto 2007: 39). The distinction between tangible and intangible heritage is thus historically and artificially constructed, but it continues to influence heritage policy and management.

As the concept of intangible cultural heritage can be seen as an East Asian 'alternative' to the Western-dominated AHD, it appears to be of particular importance to address this conceptual and practical divide when studying China. After having used the terms 'folk culture' (minjian wenhua) and 'minority culture' (minzu wenhua) for decades, China's adoption of the ICH Convention also resulted in the domestic appropriation of the concept of 'intangible cultural heritage' (feiwuzhiwenhua yichan) and 'transmitters of heritage' (chuangcheng ren). These concepts have paved the way for a new view and appreciation of many cultural practices to the extent of providing protection of traditional cultural practices that previously were regarded as 'superstitious' and 'feudal' (Gao 2014). There 
are still practices that have not received heritage status, whereas other religious practices may be reinterpreted and their religious aspects ignored or downplayed in the heritagization process, as discussed by Chan, Cooke, and Laukkanen in this volume (for other examples, see Gao 2014; Liang 2013; Chen 2015).

The dichotomy between tangible and intangible heritage is maintained in China through the domestic institutional system that entails a separation in management of these two categories of heritage. The problems caused by this and other dichotomies in the UNESCO system, such as the division between natural and cultural heritage, are discussed by Laukkanen in particular. Many of the other chapters in this volume also illustrate how it is impossible to separate tangible and intangible in the way individuals and local communities relate to heritage. Although the UNESCO ICH convention and other documents pay great attention to the involvement and ownership of local communities, this does not always happen. Transmitters are, for example, often singled out and treated more as objects in safeguarding programmes, passively passing on ICH, rather than as subjects and agents free to practise their skills and develop and recreate ICH (Beardslee 2015). They are thus often deprived of agency and voice, with government bodies, experts, and heritage middlemen speaking on their behalf and wielding the power to decide what should be listed as ICH and how it should be defined and preserved. The ICH as such rather than the individuals/transmitters tend to become the main focus and their individual rights to develop their crafts might be violated. The mixed experiences and new problems as a result of ICH policies, including issues of inclusion and exclusion, rivalry between transmitters, and difficulties to sustain or innovate and develop local crafts, are discussed in more detail in the chapters by Blumenfield, Maags, and Svensson.

\section{Chinese cultural heritage: An emerging research field}

The rapid development and importance of heritage in Chinese cultural, social, economic, and political life has led more scholars to study this phenomenon and its various dimensions. Several scholars have addressed heritage institutions and administration, policies, and the legal framework (Dutra 2004; Du Cros and Lee 2011; Shepherd and Yu 2013; Svensson 2011; Huo 2015). A number of studies have analysed the rapid development of museums and the different types of museums and exhibitions (Ashton 2013; Denton 2005; Denton 2014; Pan 2008; Nitzky 2012b; Song 2008). A great deal 
of attention has been devoted to the growing heritage tourism industry (Sofield and Li 1998; Nyíri 2006; Yan and Bramwell 2008; Su 2011; Su and Teo 2011), issues of ethnicity and heritage (Xu et al. 2006; Shepherd 2007; Kang 2009; Light 2008; Chio 2014), and the complex heritagization process of religious practices and sites (Chen 2015; Gao 2014; Le Mentec 2006; Liang 2013; and authors in Oakes and Sutton 2010). Other studies have looked at heritage practices more generally in rural (Messmer and Chuang 2013; Svensson 2006; Svensson 2012b; Oakes 2013; Zhang and Wu 2015; Zhu and Li 2013) and urban China (Fan 2014; Lee 2016; Yao and Han 2016), and also addressed special issues such as the environmental dimensions of heritage (McLaren et al. 2013). Several studies have focused on World Heritage Sites in China (Hevia 2001; Wang 2010; Zhu and Li 2013), and a growing number of scholars have in recent years addressed the Chinese ICH system and different cultural practices (Bodolec 2012; Chen 2015; Daly 2010; Gao 2014; Kuah and Liu 2017; Liang 2013; Light 2008; Obringer 2011; Wong 2009). A few scholars, notably Zongjie Wu and Song Hou, have written extensively on the global authorized heritage discourse (Wu and Hou 2015) and have also tried to elaborate on a Chinese version, identifying indigenous Chinese values and terms associated with traditional culture such as guji (ancient vestige) (Wu 2012a; Wu 2014; Hou and Wu 2012), whereas others such as Zhu (2015) have discussed how authenticity is understood in the Chinese context. The edited volume Cultural Heritage Politics in China by Blumenfield and Silverman (2013) was an important milestone that addressed a wide range of heritage issues, including heritage management practices, tourism and heritage, World Heritage Sites, ethnicity and heritage, and museum developments.

Few studies to date, however, explicitly relate to theories emerging from the critical heritage studies body of work in recent years, and many issues and perspectives on the rapidly developing Chinese heritage field are still missing. This volume aims to address some of the gaps, connect more firmly with recent theoretical developments within heritage studies, as well as build on insights from China studies and previous studies of the Chinese heritage. Our special contribution is our attempt to analyse the authorized heritage discourse in China and adopt a more bottom-up perspective that pays closer attention to how individuals and local communities negotiate with, appropriate, and, in some instances, challenge the authorized heritage discourse. We also aim to untangle contestations over memories and places, and illustrate ruptures and contradictions in heritage-making in China across time and space. In addition, we address the problems resulting from the dichotomy between intangible and tangible, and cultural and 
natural elements. Another contribution is the volume's special emphasis on the role of public debates and new media in heritage imaginations and engagements.

The authors have long experience of conducting research in China, including in some cases having worked within the conservation sector and/ or been involved in activism and public debates. They represent different fields such as history, anthropology, heritage studies, architecture and conservation, China studies, and political science. This breadth is especially valuable in order to understand the complex social and political contexts of cultural heritage contestations and manifestations in China today. The authors' different disciplinary backgrounds are also reflected in their use of different methods and ways to discuss and write heritage, ranging from historical studies to more ethnographic studies. The volume has been organized into three themes.

\section{Section I: Reimagining the past: Ruptures and contested histories, memories, and identities in contemporary society}

The new appreciation of erstwhile neglected or criticized aspects of China's past and traditions has led to a rediscovery and rewriting of many sites and places within the heritage discourse. Sites and practices that were interpreted as backward, feudal, superstitious, and exploitative during the Mao Zedong era have now been given more positive interpretations and upgraded to heritage status. The changing and multilayered readings of sites and cultural practices over time, and among different individuals and communities, draw our attention to the socially and politically constructed nature of cultural heritage. Ideological shifts, current political and economic objectives, and the existence of diverse and plural voices in society thus shape heritage discourse and policy as well as how sites are imagined and experienced. This section focuses on the evolving and sometimes contested interpretation of individual sites, neighbourhoods, and cultural practices among different actors, and the differences between the Mao Zedong era and the reform period.

Cooke's chapter addresses how the interpretation and meaning of one particular site, Ma Bufang's residence in Xining, Qinghai, has evolved and changed over time. The site has, like so many other heritage sites, emerged from oblivion during the reform period. After having been labelled a 'negative example' and used to teach class struggles, it has been listed as a protected site and turned into a public museum. Due to the site's 
multifaceted history and function as a residence of a Sino-Muslim warlord, it is deeply embedded in complex issues of ethnicity, religion, nation-making, and political struggles. This renders the site not just a site of the past, but also a site that speaks to difficult and contested issues in contemporary society. These complexities are also evident in how the site today is narrated, interpreted, and experienced. As Cooke shows in her study, the ethnic Hui culture is embodied within a national narrative, at the same time as the orthodox political heritage discourse coexists with other sub-narratives, silences, and contradictory signs and untold stories. The analysis of $\mathrm{Ma}$ Bufang's residence reminds us of the contingent, evolving, and contested nature of many heritage sites in China, and that they need to be understood in the light of both historical and contemporary issues.

China's opening up to the world has also meant a search for, or an imagining of, a more cosmopolitan past and heritage, and attempts to portray China as a multicultural society in order to attract both foreign investment and tourists. Zhang's study focuses on the former Italian concession in Tianjin, which during the Mao Zedong era was interpreted as a humiliating example of imperialism on Chinese territory but has now become a symbol of the city's cosmopolitan heritage. The 'Italian-style exotic district', its new name, is branded as reflecting authentic Italian architecture despite the fact that it in part contains reconstructed new buildings. The area has been re-evaluated as a result of ideological changes and economic reforms. The colonial legacy is now a valuable asset for Tianjin in its city branding, and the stories told are no longer that of imperialism and humiliation but of modernization, cosmopolitanism, and friendship with Italy and other foreign countries.

The rapid urban transformation in China since the early 199os has led to demolitions of whole neighbourhoods, uprooting local communities, and inner-city developments that have resulted in gentrification and the loss of local memories. At the same time, however, historic buildings and traditional environments, even if reconstructed, are highly valuable in city branding and tourism promotion. Graezer Bideau and Yan discuss the complex and evolving relationship between official and local narratives and memories in the Gulou neighbourhood in Beijing. Their study addresses the lived and embodied experience of heritage and the local community's attachments to the neighbourhood. It also analyses the role and uneven power of different actors, including local communities, heritage activists, and the local government, in urban redevelopment and heritage management. They provide insights into the arguments and views on the neighbourhood and its heritage among different actors and the public debates on the topic. 


\section{Section II: Appropriations, negotiations, and contestations: Transmitters, religious practitioners, and local communities}

The heritage boom in China is partly driven by the central state and by local governments that are motivated by both ideological and economic considerations. The top-down heritagization process has, however, given rise to new stakeholders who may have their own agendas and express different views. At the same time, the language of heritage has also opened up space for individual citizens and local communities to celebrate and safeguard their own traditions and local history. Individual citizens and communities are experiencing, performing, and documenting heritage in a more bottom-up way, sometimes outside of the state narrative, at the same time as many actors try to capitalize on the official heritage discourse in order to gain legitimacy for their own history and traditions. This section discusses the complex linkages between top-down heritage policy and bottom-up imaginations, and different attempts to appropriate the heritage discourse. The authors discuss different actors, their capacity for voice and agency, how and why they appropriate the official heritage narrative, and the emergence of new conflicts, both among these actors and in their relationship with the fragmented authoritarian state.

Maags studies the impact of the two main intangible heritage policies on individuals and communities in the cities of Jiujiang and Changzhou. Although these policies are aimed at supporting local traditions and individual cultural work, her findings show how the local implementation of these policies has brought about division and hierarchies among local stakeholders. Only a limited number of local traditions and cultural practitioners may be inscribed on governmental safeguarding lists and thus obtain state funding and support. Furthermore, inscription often depends on good connections to heritage experts and officials. Local stakeholders, such as cultural practitioners who aim to become an official representative ICH transmitter or locals who strive to have their local tradition enlisted individually, employ official heritage discourses and heritage expertise to enhance their agency and obtain legitimacy in the heritage-making process. As a result, competition for inscription leads to contestation and conflicts between members and between local communities. In identifying actors and their relationships within this local web of heritage stakeholders, Maags's chapter demonstrates how local non-state stakeholders are not passive but active participants in competing for heritage status, seeking to obtain a 'piece of the pie', as well as potentially influencing local identity construction and locality branding efforts. 
Chan discusses the actors involved in recasting the Chaozhou Hungry Ghosts Festival in Hong Kong into a piece of national cultural heritage. The Chaozhou Hungry Ghosts Festival is an important festival that has witnessed numerous transformations over the years. The local community has been able to keep the festival alive for many generations without any support or recognition from the Hong Kong government. The motivations for the bottom-up work among some local communities to have it inscribed as cultural heritage were multifaceted and complex. Chan's study shows that, on the one hand, it reflected nostalgia for a traditional lifestyle and an attempt to gain recognition for their cultural traditions and identities. But, on the other hand, among some segments of the Chaozhou community it was also a deliberate attempt to use heritage status to create stronger ties with Chaozhou communities on the mainland and express support for the mainland government. The struggle for heritage recognition in this case thus took place within the larger framework of Hong Kong identity politics and pro-China politics.

Blumenfield discusses how local communities in Yunnan are navigating heritage policies and whether, and to what extent, these policies may change people's lives and identities and the cultural practices themselves. She provides several examples and case studies that show different experiences and negotiations with the AHD. Her study of Moso weavers in Walabi village in Yunnan shows the intricate and complex ways heritage is understood and impacts on the local community. The label 'intangible cultural heritage', or 'transmitter of intangible cultural heritage', neither guarantees protection nor commercial viability for time-consuming handicraft. Blumenfield's chapter turns our attention to what heritage 'does' or 'does not' do to individuals, communities, and their cultural practices and products. It alerts us to the difficult tensions between transmission, innovation, protection, and commercial use, and whether and how local communities have a say in the protection and development of their heritage.

Laukkanen's chapter addresses religious as well as ethnic identity and heritage in a Tibetan village in the Meili Snow Mountains, which is part of the UNESCO World Heritage Site Three Parallel Rivers. Her chapter shows the complex interplay and artificial distinction between natural and cultural heritage in UNESCO's work and its impact on a local community. Although the mountains are only listed as a natural heritage site, they have deep religious significance for the Tibetan community who regard them, especially Mount Khawa Karpo, as holy mountains. The new heritage status and the preservation policy thus serve to erase and ignore the mountains' long-standing cultural significance and meaning for the local 
community. The listing and natural park status is also problematic since it seems to favour tourists' experiences at the expense of local communities' participation in and management of the area.

\section{Section III: Public debates and new forms of engagements: Voices, emotions, and new platforms}

Different actors play different roles and have different levels of power in the heritage field. Their social and cultural capital, discursive strategies, and ability to use the media also influence whether their voices are heard. Cultural heritage debates are highly mediated and visualized thanks to the growing importance of the Internet and social media and the ubiquitous use of images. Online platforms open up new arenas that enable individuals to come together to debate and circulate their views and experiences, and engage with and react to the official heritage discourse, policies, and individual protection programmes. Heritage experts and government bodies today need to take the public's views into account and new relationships among heritage stakeholders have emerged as a result. The new platforms encourage engagements that strengthen old communities as well as create new heritage communities. Many Chinese citizens are today interested in celebrating, experiencing, performing, and documenting the heritage in a more personalized way through their own images and texts outside of the heritage institutions. We see new performative celebrations of individual memories and local cultural heritage, as well as strong emotions and affective engagement with heritage that reveal underlying anxieties in society and the role heritage can play in strengthening identity and regaining local and national pride.

Cui analyses the role and vision of one remarkable political leader, Geng Yanbo, who served as the mayor of Datong during the period 2008-2013. Geng's vision and strong charisma shaped the city's heritage policy and radically changed the urban fabric during his term in office. This intriguing case shows the importance of individual leadership, the role of heritage in urban development and city branding, and the complex understandings of heritage among different actors. Geng embarked on an ambitious renovation programme that also included moving, changing, and 'improving' many historic buildings, and even constructing 'fake' historic buildings. Although many aspects of his work were strongly criticized by heritage experts and state bodies, including SACH, which called for several projects to be brought to a halt, they were at first not able to stop Geng, who also 
received strong support from local citizens. The debate was carried out both in traditional media and on the Internet, including social media platforms such as Sina Weibo. The supporters and Geng himself saw the programme as an attempt at cultural revival, and argued that it would improve the cultural and historic quality of the city. Very different views and interpretations of what heritage is and how preservation should be carried out were thus at the heart of the debate. The case reveals how expert views, political visions, and public sentiments are complex and sometimes clash. It also illustrates how influential and powerful individual political leaders can be in an authoritarian system.

Tam discusses another case of a heated public debate on heritage and preservation that, however, took place on a smaller scale, involved other actors, and revealed a different power asymmetry. Her chapter focuses on the revitalization of the Zhizhu Temple in Beijing. The temple has not been a site for religious activities since 1949 and was then used for many different purposes, including as factories. Although it was listed as a Beijing Municipal Protected Site in 1984, it was not restored until 2007. After many years of neglect, a company leased the temple and, with the approval of the Beijing Bureau of Cultural Heritage, started to renovate it in order to turn it into an upmarket hotel, a restaurant, and an art gallery. The renovation earned the company a UNESCO Asia-Pacific Awards of Cultural Heritage Conservation in 2012. Criticism was, however, voiced in both official media and by individual citizens over the fact that a former temple was used for secular purposes and had become a 'private club'. The case and debate illustrates both complex and unclear regulations and different views and visions among different actors on how to preserve and reuse heritage sites. It also illustrates the important role of the media in how heritage debates are framed, and the strong emotions heritage may inspire among many citizens.

Svensson provides another example of citizens' affective engagement with the cultural heritage, both online and offline. Her chapter focuses on how the Internet and social media have created new forms of engagements with heritage that are more individual and performative in character. She discusses the network Taishun (later China) Covered Bridges, which got its first online presence in 2000 when the founder set up a website. What started out as a website and loose network of a small number of friends and enthusiasts has now developed into a registered organization with a presence on social media. While most of the core group are from Taishun, the larger network also gathers experts and enthusiasts from different parts of China. They engage with the local heritage in different ways, documenting local history and traditions, calling for the protection 
of sites, and creating awareness on heritage issues more generally. Their engagement online also exhibits some new features as heritage has become more performative, visual, and participatory in nature. The use of social media means that people can share information, comment on each other's postings, and upload images and news in real time. This bottom-up network is not pushing for the recognition of a different kind of heritage, and it has quite good relations with the local government and heritage officials, but it shows stronger affective engagement and reveals how people are able to incorporate, reflect upon, and perform heritage in their everyday life.

\section{References}

ACHS (2012). 'History', Association for Critical Heritage Studies web site, http:// www.criticalheritagestudies.org/history/.

Ashton, Curtis (2013). 'Beijing Museums in the Context of the 2008 Beijing Olympics', in Cultural Heritage Politics in China, ed. by Tami Blumenfield and Helaine Silverman (New York: Springer), 187-203.

Ashworth, G.J. (2014). 'Heritage and Economic Development: Selling the Unsellable', Heritage and Society, 7 (1): 3-17.

Askew, David (2010). 'The Magic List of Global Status: UNESCO, World Heritage and the Agenda of States', in Heritage and Globalisation, ed. by Sophia Labadi and Colin Long (New York: Routledge), 19-44.

Beardslee, Thomas (2015). 'Whom Does Heritage Empower, and Whom Does It Silence? Intangible Cultural Heritage at the Jemaa el Fnaa, Marrakech', International Journal of Heritage Studies, 22 (2): 89-101.

Bendix, Regina F., Aditya Eggert and Arnika Peselman (eds) (2012). Heritage Regimes and the State (Göttingen: Universitätsverlag Göttingen).

Blumenfield, Tami, and Helaine Silverman (eds) (2013). Cultural Heritage Politics in China (New York: Springer).

Bodolec, Caroline (2012). 'The Chinese Paper-Cut: From Local Inventories to the UNESCO: Representative List of the Intangible Cultural Heritage of Humanity', in Heritage Regimes and the State, ed. by Regina F. Bendix, Aditya Eggert and Arnika Peselman (Göttingen: Universitätsverlag Göttingen), 249-264.

Bortolotto, Chiara (2007). 'From Objects to Processes: UNESCO's Intangible Cultural Heritage', Journal of Museum Ethnography, 19: 21-33.

CASS (2016). 'China's Intangible Cultural Heritage', Chinese Academy of Social Sciences, http://iel.cass.cn/english/Detail.asp?newsid=2393. 
Chen, Zhiqin (2015). 'For Whom to Conserve Intangible Cultural Heritage: The Dislocated Agency of Folk Belief Practitioners and the Reproduction of Local Culture', Asian Ethnology, 74 (2): 307-334.

Chio, Jenny (2006). A Landscape of Travel: The Work of Tourism in RuralEthnic China (Seattle: University of Washington Press).

Coombe, Rosemary J. (2015). 'Managing Cultural Heritage as Neoliberal Governmentality', in Heritage Regimes and the State, ed. by Regina F. Bendix, Aditya Eggert and Arnika Peselman (Göttingen: Universitätsverlag Göttingen), 375-387. Crouch, David (2015). 'Affect, Heritage, Feeling', in The Palgrave Handbook of Contemporary Heritage Research, ed. by Emma Waterton and Steve Watson (Basingstoke: Palgrave Macmillan), 177-19o.

Daly, Patrick (2010). 'Fighting Modernity: Traditional Chinese Martial Arts and the Transmission of Intangible Cultural Heritage', in Routledge Handbook of Heritage in Asia, ed. by Patrick Daly and Tim Winter (New York: Routledge), 350-363.

Denton, Kirk A. (2005). 'Museums, Memorial Sites and Exhibitionary Culture in the People's Republic of China', China Quarterly, 183: 565-586.

Denton, Kirk A. (2014). Exhibiting the Past: Historical Memory and the Politics of Museums in Postsocialist China (Honolulu: University of Hawai'i Press).

Dicks, Bella (2003). 'Heritage, Governance and Marketization: A Case-study from Wales', Museum and Society, 1 (1): 30-44.

Du Cros, Hilary, and Yok-shiu F. Lee (2011). Cultural Heritage Management in China (London: Routledge).

Dutra, Michael (2004). 'Sir, How Much Is That Ming Vase in the Window? Protecting Cultural Relics in the People's Republic of China', Asia Pacific Law and Policy, 5:65-100.

Fan, Li (2014). 'International Influence and Local Response: Understanding Community Involvement in Urban Heritage Conservation in China', International Journal of Heritage Studies, 20 (6): 651-662.

Gao, Bingzhong (2014). 'How Does Superstition Become Intangible Cultural Heritage in Postsocialist China?', Positions (Asia Critique), 22 (3): 551-572.

Gao, Mabo (2008). The Battle for China's Past: Mao and the Cultural Revolution (London: Pluto Press).

Germundsson, Tomas (2005). 'Regional Cultural Heritage versus National Heritage in Scania's Disputed National Landscape', International Journal of Heritage Studies, 11 (1): 21-37.

Hafstein, Valdimar T. (2009). 'Intangible Heritage as a List', in Intangible Heritage, ed. by Laurajane Smith and Natsuko Akagawa (London: Routledge), 142-175.

Hafstein, Valdimar T. (2012). 'Cultural Heritage', in A Companion to Folklore, ed. by Regina F. Bendix and Galit Hasan-Rokem (Chichester Wiley-Blackwell), 500-519. 
Haldrup, M., and J.O. Bærenholdt (2015). 'Heritage as Performance', in The Palgrave Handbook of Contemporary Heritage, ed. by E. Waterton and S. Watson (Basingstoke: Palgrave Macmillan), 52-68.

Harrison, Rodney (2013). Heritage: Critical Approaches (London: Routledge).

Harvey, David (2001). 'Heritage Pasts and Heritage Presents: Temporality, Meaning and the Scope of Heritage Studies', International Journal of Heritage Studies, 7 (4): 319-338.

Hevia, J.L. (2001). 'World Heritage, National Culture, and the Restoration of Chengde', Positions: East Asia Cultures Critique, 9 (1): 219-243.

Hou, Song, and Zongjie Wu (2012). '“Guji” yu yichan zhengzhi de kua wenhua jiedu' ['Guji' and cross-cultural interpretations on heritage politics], Wenhua yishu yanjiu [Studies in culture and art], 1: 1-8.

Huo, Zhengxin (2015). 'Legal Protection of Cultural Heritage in China: A Challenge to Keep History Alive', International Journal of Cultural Policy, 10.1080/10286632.2015.1015534.

Kang, Xiaofei (2009). 'Two Temples, Three Religions, and a Tourist Attraction: Contesting Sacred Space on China's Ethnic Frontier', Modern China, 35 (3): 227-255.

Kuah, Khun Eng, and Zhaohui Liu (2017). Intangible Cultural Heritage in Contemporary China: The Participation of Local Communities (London: Routledge).

Kuutma, K. (2009). 'Cultural Heritage: An Introduction to Entanglements of Knowledge, Politics and Property', Journal of Ethnology and Folkloristics, 3 (2): 5-12.

Lee, Anna Ka-yin (2016). 'Heritage Conservation and Advocacy Coalitions: The State-Society Conflict in the Case of the Enning Road Redevelopment Project in Guangzhou', International Journal of Heritage Studies, 22 (9): 729-747.

Le Mentec, Katiana (2006). 'The Three Gorges Dam Project - Religious Practices and Heritage Conservation: A Study of Cultural Remains and Local Popular Religion in the Xian of Yunyang (Municipality of Chongqing)', China Perspectives, $65: 2-13$.

Li, Cheng (ed.) (2011). China's Emerging Middle Class: Beyond Economic Transformation (Washington, DC: Brookings Institution Press).

Liang, Yongjia (2013). 'Turning Gwer Sa La Festival into Intangible Cultural Heritage: State Superscription of Popular Religion in Southwest China', China: An International Journal, 11 (2): 58-75.

Lieberthal, Kenneth, and Michel Oksenberg (1988). Policy Making in China:Leaders, Structures, and Processes (Princeton: Princeton University Press).

Light, D., C. Prentice, G.J. Ashworth and J. Larkham (1994). Who Consumes the Heritage Product? Implications for European Tourism (London: Routledge).

Light, Nathan (2008). Intimate Heritage: Creating Uyghur Muqam Song in Xinjiang (Hamburg: LIT Publications). 
Long, Colin (2012). 'Modernity, Socialism and Heritage in Asia', in Routledge Handbook of Heritage in Asia, ed. by Patrick Daly and Tim Winter (New York: Routledge): 201-217.

Maags, Christina, and Heike Holbig (2016). 'Replicating Elite-Dominance in Intangible Cultural Heritage Safeguarding: The Role of Local GovernmentScholar Networks in China', International Journal of Cultural Property, 23: 71-97.

Madsen, Richard (2014). 'From Socialist Ideology to Cultural Heritage: The Changing Basis of Legitimacy in the People's Republic of China', Anthropology \& Medicine, 21 (1): 58-70.

McLaren, Anne E., Alex English and Xinyuan He (2013). Environmental Preservation and Cultural Heritage in China (Champaign: Common Ground Publishing).

Meskell, L., C. Liuzza, E. Bertacchini and D. Saccone (2015). 'Multilateralism and UNESCO World Heritage: Decision-making, States Parties and Political Processes', International Journal of Heritage Studies, 21 (5): 423-440.

Messmer, Matthias, and Hsin-Mei Chuang (2013). China's Vanishing Worlds: Countryside, Traditions, and Cultural Spaces (Cambridge, MA: MIT Press).

Nitzky, William (2012a). 'Ecomuseums with Chinese Characteristics: The Politics of Safeguarding Living Heritage', in Proceedings of the 1st International Conference on Ecomuseums, Community Museums and Living Museums, ed. by Sergio Lira (Green Lines Institute for Sustainable Development), 259-270.

Nitzky, William (2012b). 'Mediating Heritage Preservation and Rural Development: Ecomuseum Development in China', Urban Anthropology, 41 (2-4): 367-417.

Nitzky, William (2013). 'Community Empowerment at the Periphery? Participatory Approaches to Heritage Protection in Guizhou, China', in Cultural Heritage Politics in China, ed. by Tami Blumenfield and Helaine Silverman (New York: Springer), 205-233.

Nyíri, Pál (2006). Scenic Spots: Chinese Tourism, the State, and Cultural Authority (Seattle: University of Washington Press).

Oakes, Tim (2013). 'Heritage as Improvement: Cultural Display and Contested Governance in Rural China', Modern China, 39 (4), 380-407.

Oakes, Tim, and Donald S. Sutton (eds) (2010). Faiths on Display: Religion, Tourism and the Chinese State (Lanham: Rowman \& Littlefield).

Obringer, F. (2011). 'Chinese Medicine and the Enticement of Heritage Status', China Perspectives, 3: 15-22.

Pan, Shouyong (2008). 'Museums and the Protection of Cultural Intangible Heritage', Museum International, 60 (1-2): 12-19.

Robertson, Ian J.M. (2012). Heritage from Below (Farnham: Ashgate).

Shepherd, Robert (2007). 'UNESCO and the Politics of Cultural Heritage in Tibet', Journal of Contemporary Asia, 36 (2): 243-257. 
Shepherd, Robert J., and Larry Yu (2013). Heritage Management, Tourism, and Governance in China (New York: Springer).

Silverman, Helen (ed.) (2011). Contested Cultural Heritage: Religion, Nationalism, Erasure and Exclusion in a Global World (New York: Springer).

Silverman, Helaine, and Tami Blumenfield (2013). 'Cultural Heritage Politics in China: An Introduction', in Cultural Heritage Politics in China, ed. by Tami Blumenfield and Helaine Silverman (New York: Springer), 3-23.

Smith, Laurajane (2006). Uses of Heritage (London: Routledge).

Smith, Laurajane (2015). 'Intangible Heritage: A Challenge to the Authorised Heritage Discourse?', Revista d'Etnologia de Catalunya, 40, http://www.raco.cat/index. php/RevistaEtnologia/article/download/293392/381920.

Sofield, Trevor, and Fung Mei Sarah Li (1998). 'Tourism Development and Cultural Policies in China', Annals of Tourism Research, 25 (2): 362-392.

Song, Xiangguang (2008). 'The Development of Private Museums in China', Museum International, 60 (1-2): 40-48.

$\mathrm{Su}$, Xiaobo, and Peggy Teo (2011). The Politics of Heritage Tourism in China: A View from Lijiang (London: Routledge).

Svensson, Marina (2006). 'In the Ancestor's Shadow: Cultural Heritage Contestations in Chinese Villages', Working Paper 17, Centre for East and South-East Asian Studies, Lund University, Sweden.

Svensson, Marina (2011). 'Cultural Heritage Protection in the People's Republic of China: Preservation Policies, Institutions, Laws, and Enforcement in Zhejiang', in Making Law Work: Chinese Laws in Context, ed. by Mattias Burell and Nina Svensson (Ithaca: Cornell University Press), 225-266.

Svensson, Marina (2012a). 'Heritage Struggles and Place-makings in Zhejiang Province: Local Media, Cross-regional Media Interactions, and Media Strategies from Below', in Mapping Media in China: Region, Province and Locality, ed. by W. Sun and J. Chio (London: Routledge), 193-211.

Svensson, Marina (2012b). 'Lineages and the State in Zhejiang: Negotiating and Re-inventing Local History and Heritage', in Organizing Rural China, ed. by Ane Bislev and Stig Thøgersen (Lanham: Rowman \& Littlefield), 157-172.

Tunbridge, J.E., and G.L. Ashworth (1996). Dissonant Heritage: The Management of the Past as a Resource in Conflict (Chichester: John Wiley).

UNESCO (2014). 'Silk Roads: The Routes Network of Chang'an-Tianshan Corridor', http://whc.unesco.org/en/list/1442.

UNESCO (2015). 'Patronage Request', http://www.unesco.org/culture/ich/en/state/ china-CN?info=activities-with-the-patronage.

UNESCO (2016a). 'China', http://whc.unesco.org/en/statesparties/cn.

UNESCO (2016b). 'Elements on the Lists', http://www.unesco.org/culture/ich/en/ state/china-CN?info=elements-on-the-lists. 
Wang, Dong (2010). 'Internationalizing Heritage: UNESCO and China's Longmen Grottoes', China Information, 24 (2): 123-147.

Wang, Hong-luen (2012). 'War and Revolution as National Heritage: Red Tourism in China', in Routledge Handbook of Heritage in Asia, ed. by Patrick Daly and Tim Winter (New York: Routledge), 218-233.

Waterton, Emma (2014). 'A More-Than-Representational Understanding of Heritage? The "Past" and the Politics of Affect', Geography Compass, 8 (11): 823-833.

Waterton, Emma, and Steve Watson (2013). 'Framing Theory: Towards a Critical Imagination in Heritage Studies', International Journal of Heritage Studies, 19 (6): 546-561.

Winter, Tim (2013). 'Clarifying the Critical in Critical Heritage Studies', International Journal of Heritage Studies, 19 (6): 532-545.

Winter, Tim (2014). 'Heritage Studies and the Privileging of Theory', International Journal of Heritage Studies, 20 (4): 556-572.

Wong, Isabel K.F. (2009). 'The Heritage of Kunqu: Preserving Music and Theater Traditions in China', in Intangible Heritage Embodied, ed. by D. Fairchild Ruggles and Helaine Silverman (New York: Springer), 15-35.

Wu, Zongjie (2012a). 'Recovering Indigenous Discourse of Cultural Heritage: A Chinese Challenge to Western Value of Heritage',Journal of Zhejiang University (Humanities and Social Sciences), 2012/05.

Wu, Zongjie (2012b). 'Transdisciplinary and Cross-Cultural Turn of Critical Discourse Studies: A Case of Remaking Chinese Cultural Heritage Discourse', Journal of Guangdong University of Foreign Studies, 2012/06.

Wu, Zongjie (2014). 'Let Fragments Speak for Themselves: Vernacular Heritage, Emptiness and Confucian Discourse of Narrating the Past', International Journal of Heritage Studies, 20 (7-8): 851-865.

$\mathrm{Wu}$, Zongjie, and Song Hou (2015). 'Heritage and Discourse', in The Palgrave Handbook of Contemporary Heritage Research, ed. by Emma Waterton and Steve Watson (Hampshire: Palgrave Macmillan), 37-51.

Xu, J., E.T. Ma, D. Tashi, Y. Fu, Z. Lu and D. Melick (2005). 'Integrating Sacred Knowledge for Conservation: Cultures and Landscapes in Southwest China', Ecology and Society, 10 (2): art. 7.

Yan, Hongliang, and Bill Bramwell (2008). 'Cultural Tourism, Ceremony and the State in China', Annals of Tourism Research, 35 (4): 969-989.

Yao, Yuan, and Rongbin Han (2016). 'Challenging, but Not Trouble-Making: Cultural Elites in China's Urban Heritage Preservation', Journal of Contemporary China, 25 (98): 292-306.

Yu, Hua (2015). 'A Vernacular Way of "Safeguarding” Intangible Heritage: The Fall and Rise of Rituals in Gouliang Miao Village', International Journal of Heritage Studies, 21 (10): 1016-1035. 
Zhang, Yingchun, and Zongjie Wu (2015). 'The Reproduction of Heritage in a Chinese Village: Whose Heritage, Whose Pasts?', International Journal of Heritage Studies, 22 (3): 228-241.

Zhu, Yujie (2015). 'Cultural Effects of Authenticity: Contested Heritage Practices in China', International Journal of Heritage Studies, 21 (6): 594-6o8.

Zhu, Yujie, and Na Li (2013). 'Groping for Stones to Cross the River: Governing Heritage in Emei', in Cultural Heritage Politics in China, ed. by Tami Blumenfield and Helaine Silverman (New York: Springer), 51-71.

\section{About the authors}

Marina Svensson, Professor of Modern China Studies, Centre for East and SouthEast Asian Studies, Lund University, Sweden

Christina Maags, Lecturer in Chinese Politics, School of Oriental and Asian Studies (SOAS), University of London, UK 